\title{
Retraction Note to: The change of groundwater quality in shallow layer based on parameter estimation and tennis physical fitness recovery
}

\author{
Zixuan Geng $^{1}$
}

Published online: 3 November 2021

(c) Saudi Society for Geosciences 2021

Retraction Note to: Arabian Journal of Geosciences (2021) 14: 1491 https://doi.org/10.1007/s12517-021-08009-y

The Editor-in-Chief and the Publisher have retracted this article because the content of this article is nonsensical. The peer review process was not carried out in accordance with the Publisher's peer review policy. The author has not responded to correspondence regarding this retraction.

Publisher's note Springer Nature remains neutral with regard to jurisdictional claims in published maps and institutional affiliations.

The original article can be found online at https://doi.org/10.1007/ s12517-021-08009-y.

Zixuan Geng

vogp103037601@163.com

1 Zhengzhou University of Technology, Zhengzhou 450044,

China 